\title{
RETURN OF NORMAL TESTICULAR ACTIVITY IN CURED PATIENTS OF LYMPHOMA
}

\author{
Sanaullah Kuchay', Zahoor Ahmad Paul2, Mushood Nabi
}

${ }^{1}$ Associate Professor and HOD, Department of Radiation Oncology, Government Medical College, Srinagar, Jammu and Kashmir, India. ${ }^{2}$ Senior Resident, Department of Radiation Oncology, Government Medical College, Srinagar, Jammu and Kashmir, India. ${ }^{3}$ Assistant Professor, Department of Radiation Oncology, Government Medical College, Srinagar, Jammu and Kashmir, India.

\section{ABSTRACT}

\section{BACKGROUND}

For young patients cured of lymphoma, the major concern is gonadal dysfunction with impaired reproductive capacity. This has a bearing on the social well-being and self-esteem of these otherwise cured patients. Pretreatment infertility is a significant problem in males having Hodgkin's lymphoma. This already compromised testicular activity further deteriorates with chemotherapy and radiotherapy. Recovery of testicular activity after cure and subsequent cessation of treatment reaches a peak at around 5 years. Further longer follow-up beyond five years has demonstrated varying results of improvement and return of normal testicular activity.

\section{AIM}

To determine impact of treatment and long-term follow-up on return of normal testicular activity in patients cured of lymphoma.

\section{MATERIALS AND METHODS}

Prospective study comprising 30 newly diagnosed male patients with histopathological diagnosis of lymphoma. Semen analysis, serum FSH and LH levels were determined pretreatment, immediately after completion of therapy and yearly till 20 years (From 1994-2014). Pretreatment, immediate post-treatment, 5-year and 20-year observations are evaluated for presentation.

\section{RESULTS}

Pretreatment infertility was present in $13.47 \%$ of patients. After completion of treatment, $77.50 \%$ developed azoospermia. However, after initial follow-up of 5 years, percentage of normospermic patients returned to $42.93 \%$, recovery being better in patients of age less than 30 years. Reevaluation of 18 cured patients at a further 20 years follow-up demonstrated no further significant recovery.

\section{CONCLUSION}

The effect of cyclophosphamide and procarbazine containing chemotherapy is significant compared to the patients who received combinations without procarbazine. Initial recovery of testicular functions achieved at 5 years was less likely to improve significantly even after a prolonged follow-up period of 20 years.

\section{KEYWORDS}

Hodgkin's Lymphoma, Non-Hodgkin's Lymphoma, Semen Analysis, FSH, LH.

HOW TO CITE THIS ARTICLE: Kuchay S, Paul ZA, Nabi M. Return of normal testicular activity in cured patients of lymphoma J. Evolution Med. Dent. Sci. 2016;5(78):5811-5815, DOI: 10.14260/jemds/2016/1311

\section{INTRODUCTION}

Currently, a significant proportion of young patients have long-term survival following chemotherapy for lymphomas, germ cell tumours and acute leukaemia, etc. However, the major concern for the cured patients is gonadal dysfunction with impaired reproductive capacity. Most of these chemotherapy protocols use the drugs in large doses that may be toxic to gonads. The degree to which testicular function is affected is dose and agent dependent. 1,2 In men treated for lymphoma, recovery of spermatogenesis has to begin at the beginning after drug-induced azoospermia occurs that continues until the germ cells repopulate the testes adequately for the spermatogenic process of differentiation and

Financial or Other, Competing Interest: None.

Submission 14-04-2016, Peer Review 25-04-2016,

Acceptance 28-04-2016, Published 28-09-2016.

Corresponding Author:

Sanaullah Kuchay,

Department of Radiation Oncology,

Government Medical College,

Srinagar, Jammu \& Kashmir, India.

E-mail: sanaullahkuchaysgr@gmail.com

DOI: $10.14260 /$ jemds/2016/1311

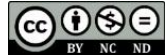

maturation. Azoospermia lasting only weeks to months reflects transient damage to late differentiating spermatogonia, whereas a delay of years for recovery point to widespread damage of even early spermatogonia and stem cells. ${ }^{2}$ Patients having the largest reductions in their sperm concentration after treatment require the longest recovery period for spermatogenesis. Germinal epithelium is particularly susceptible to injury by cytotoxic drugs and radiation due to its high mitotic rate, although Leydig's and Sertoli's cell function is often preserved due to their very low proliferation index.

This results in halted spermatogenesis, leaving testosterone function unaffected. ${ }^{3}$ As the gonads and pituitary gland function in feedback mechanism, serum assays of FSH and Luteinizing Hormone ( $\mathrm{LH}$ ) may well be useful markers for assessing the functional status of the germinal epithelium. Considerable evidence suggests that depletion of germinal epithelium leads to decrease in secretion of "INHIBIN" from Sertoli cells with subsequent elevation of serum FSH levels. ${ }^{3}$ LH is a feasible marker for assessing Leydig cell function. ${ }^{4}$

In the earlier retrospective studies, determination of gonadal dysfunction following lymphoma treatment has been documented with the help of semen analysis and/or hormonal 
assays of FSH and LH. We studied hormonal assays FSH and LH with sperm counts to assess testicular function both before and after completion of the treatments and at 05 years and 20 years follow-up to determine the effects of disease and the early and delayed effects of treatment.

\section{MATERIAL AND METHODS}

This study was conducted in the Departments of Medical and Radiation Oncology at Sher-I-Kashmir Institute of Medical Sciences. Study comprised of 30 newly diagnosed male patients of lymphoma treated between Jan. 1993 - Dec. 1994. A written, informed consent was taken from the patients and ethical approval was sought from Ethical Committee. Patient's mean age was 28.34 years ranging from 19 to 44 years. All patients had histopathological confirmation of diagnosis of lymphoma and were staged as per Ann-Arbor staging. Besides a detailed sexual history routine complete blood counts, ESR, liver and kidney function tests, serum LDH and uric acid, semen analysis and serum assays for FSH and LH was done by radio-immune assay prior to initiation of treatment.

Prior to collection of semen and hormone profile, patients were asked for sexual abstinence for 72 hours and blood samples were collected at $10.00 \mathrm{AM}$ (to avoid diurnal variation). Semen was analysed within half an hour of collection, for volume consistency, sperm count, motility and morphology. On the basis of sperm count, patients were divided into normospermic with sperm count of $>20 \times 10^{6} / \mathrm{mL}$; oligospermic with sperm count $<20 \times 10^{6} / \mathrm{mL}$ to $0.1 \times 10^{6} / \mathrm{mL}$; severe oligospermic $<0.1 \times 10^{6} / \mathrm{mL}$; azoospermic with zero sperm count.

Patients received combination chemotherapy, radiotherapy (None received infra-diaphragmatic radiotherapy) as per the indications. During the treatment period, they were followed monthly to see the response and monitor adverse effects if any. On completion of treatment, patients were reassessed for the disease as well as gonadal activity. All baseline investigations were repeated along with semen analysis and hormonal assay.

Patients were followed yearly for 20 years till December 2014 to study delayed response of treatment on testes, side effects and development of second malignancy. The data was compiled to find the recovery of spermatogenesis, treatment and effects of various factors at presentation, drug regimens, duration of follow-up and histology. Patients with bulky disease received involved field radiation in the dose of 3000 to 3500 cGy in 3 weeks in addition to chemotherapy. However, no patient received infradiaphragmatic radiation.

\section{STATISTICS}

Evaluation of the data was done using student's ' $t$ ' test (Paired), analysis of variance test was used for comparing the two groups, whereas for quantitative data chi square test was applied.

\section{RESULTS}

All 30 patients completed treatment, but only 27 patients having achieved remission were available for immediate posttreatment analysis. The mean age of patients was 29.45 years (Range 19 to 44 years). Stage I comprised 07 patients, stage II fourteen, stage III 04 and 05 patients had Stage IV disease.
Twelve patients had B-symptoms. Histologically, twelve patients had HL and 18 patients had NHL. At completion of treatment all the thirty patients were evaluated, $90 \%(\mathrm{n}=27)$ had achieved remission and were available for immediate post-treatment evaluation. Of the 3 patients opting out of study, 02 had evidence of disease on ultrasonography and 01 patient had CNS relapse (Infiltration by high-grade immunoblastic lymphoma), who expired after two months.

The mean pretreatment FSH was $6.12 \mathrm{IU} / \mathrm{L}$, increased five-fold with treatmentand declined gradually thereafter. The variation in FSH was associated with a parallel variation in sperm count, but the effect on LH was not significant (Table 1). Pretreatment sperm count was $59.23 \times 10^{6} / \mathrm{mL}$ compared to $12.88 \times 106 / \mathrm{mL}$ at completion of treatment, the difference being significant with $\mathrm{p}$ value $<0.05$. Mean pretreatment serum LH was $7.80 \mathrm{IU} / \mathrm{L}$ compared to $8.79 \mathrm{IU} / \mathrm{L}$ at completion of treatment $\mathrm{p}=\mathrm{ns}$ (Table 1$)$.

Both FSH and sperm count demonstrated a significant recovery at 5 years, but a further follow-up of 20 years did not show any significant recovery beyond that achieved at 5 years. Difference in the testicular activity before and after treatment of HL and NHL is shown in (Table 2). Pretreatment, posttreatment and follow-up results demonstrated insignificant difference with regard to type of lymphoma.

Various drug regimens used for the treatment on testicular activity had varied effect (Table 3). COPP regimen was found most gonadotoxic; $100 \%$ patients were normospermic before treatment, at completion 91\% had azoospermia and after follow-up of almost five years $90 \%$ continued with that. The effect of cyclophosphamide and procarbazine combination on sperm count and hormone levels (FSH) was significant. With CHOP regimen, recovery rate of normospermia.

When effects of chemotherapy were analysed according to age $(<30$ years vs. $>30$ years), the difference in $\mathrm{FSH}, \mathrm{LH}$ levels and sperm counts were insignificant (Table 4).

Though pretreatment, post-treatment and 20-year follow-up results demonstrated no significant difference with respect to age, yet the only significant change observed was the highest rate of recovery in patients aged less than 30 years at 60 months follow-up $(\mathrm{p}<0.05)$. Sperm counts recovered to normal in $59.61 \%$ of patients of $<30$ years age and in $18.69 \%$ of $>30$ years of age $(p<.05)$.

Patients were also divided in 3 groups on the basis of their follow-up period, one with a follow-up of $>1$ years $(n=27)$ and 2nd group with a follow-up of $>5$ years $(n=21)$ and $3^{\text {rd }}$ with a follow-up of $>20$ years $(n=18)$. Results are depicted as per Table 5. The FSH and sperm count has significantly improved in patients with a follow-up of more than 5 years as compared to those having a follow-up of less than 1 year. Eighty three percent of patients of less than one year followup period were azoospermic compared to $33.3 \%$ patients having five-year follow-up ( $p<0.05$ ); at further follow-up of 20 years twenty nine percent patients had persistent azoospermia demonstrating no further significant improvement $(\mathrm{p}=\mathrm{ns})$ (Table 1). None of our patients had any evidence of second malignancy. 


\begin{tabular}{|c|c|c|c|c|c|c|c|}
\hline $\begin{array}{l}\text { Values } \\
\text { (Mean) }\end{array}$ & $\begin{array}{c}\text { Pre- } \\
\text { Treatment } \\
(n=30)\end{array}$ & $\begin{array}{c}\text { At } \\
\text { Completion } \\
\text { of } \\
\text { Treatment } \\
(\mathrm{n}=27)^{*}\end{array}$ & $\begin{array}{c}\text { P value } \\
\text { Pre-Treat vs } \\
\text { Completion of } \\
\text { Treatment }\end{array}$ & $\begin{array}{c}\text { At } \\
\text { Follow- } \\
\text { up of } \\
60 \\
\text { Months } \\
(n=21)^{* *}\end{array}$ & $\begin{array}{c}\text { P value } \\
\text { Completion } \\
\text { versus } \\
60 \text { months }\end{array}$ & $\begin{array}{c}\text { At Follow-up } \\
\text { of } 20 \text { years } \\
(\mathbf{n = 1 8})^{* * *}\end{array}$ & $\begin{array}{l}\text { P value } \\
5 \text { years } \\
\text { versus } \\
20 \text { years }\end{array}$ \\
\hline FSH & 6.12 & 30.98 & $<0.05$ & 12.46 & $<0.05$ & 10.27 & $\mathrm{P}=\mathrm{ns}$ \\
\hline $\mathrm{LH}$ & 7.80 & 8.79 & $\mathrm{P}=\mathrm{ns}$ & 8.69 & $\mathrm{P}=\mathrm{ns}$ & 7.91 & $\mathrm{P}=\mathrm{ns}$ \\
\hline $\begin{array}{l}\text { Sperm } \\
\text { Count }\end{array}$ & 59.23 & 12.88 & $<0.05$ & 21.41 & $<0.05$ & 24.10 & $\mathrm{P}=\mathrm{ns}$ \\
\hline \multicolumn{8}{|c|}{ Table 1} \\
\hline
\end{tabular}

*Though all 30 patients completed treatment, yet only 27 were available for evaluation, 3 patients with residual disease opted out of study, ${ }^{* *} 03$ patients died, 3 lost for follow-up, ${ }^{* * *} 02$ died, 1 opted out of study.

\begin{tabular}{|c|c|c|c|}
\hline Parameter & $\begin{array}{l}\text { Hodgkin's Lymphoma } \\
\text { Mean (Range) } \mathrm{N}=12\end{array}$ & $\begin{array}{c}\text { Non-Hodgkin's Lymphoma } \\
\text { Mean (Range) N=18 }\end{array}$ & P Value \\
\hline $\begin{array}{c}\text { FSH (IU/L) } \\
\text { Pre-treatment } \\
\text { Post-treatment } \\
\text { Follow-up } 5 \text { yrs. } \\
\text { At } 20 \text { years }\end{array}$ & $\begin{array}{c}6.62(2.21-22.4) \\
38.92(4.56-99.24) \\
18.41(2.21-78.12) \\
12.81(2.10-73.01)\end{array}$ & $\begin{array}{c}5.62(2.41-16.0) \\
22.86(2.58-99.6) \\
6.51(2.50-24.89) \\
7.73(2.43-23.79)\end{array}$ & $\begin{array}{l}\text { Ns } \\
\text { Ns } \\
\text { Ns } \\
\text { Ns }\end{array}$ \\
\hline $\begin{array}{c}\text { LH }(\mathrm{IU} / \mathrm{L}) \\
\text { Pre-treatment } \\
\text { Post-treatment } \\
\text { Follow-up } 5 \text { yrs. } \\
\text { At } 20 \text { years }\end{array}$ & $\begin{array}{c}6.27(3.0-9.4) \\
8.85(3.1-10.5) \\
9.52(2.0-23.35) \\
8.87(2.0-22.12)\end{array}$ & $\begin{array}{c}9.33(1.20-12.40) \\
8.73(1.24-17.00) \\
7.86(1.21-25.88) \\
6.95(2.88-21.39)\end{array}$ & $\begin{array}{l}\text { Ns } \\
\text { Ns } \\
\text { Ns } \\
\text { Ns }\end{array}$ \\
\hline $\begin{array}{c}\text { Sperm count x } 106 / \mathrm{L} \\
\text { Pre-treatment } \\
\text { Post-treatment } \\
\text { Follow-up } 5 \text { yrs. } \\
\text { At } 20 \text { years }\end{array}$ & $\begin{array}{c}53.11(0-90) \\
11.23(0-49) \\
15.98(0-84) \\
23.77(0-87)\end{array}$ & $\begin{array}{c}65.35(0-156) \\
14.53(0-86) \\
26.84(0-96) \\
24.43(0-87)\end{array}$ & $\begin{array}{l}\text { Ns } \\
\text { Ns } \\
\text { Ns } \\
\text { Ns }\end{array}$ \\
\hline
\end{tabular}

\begin{tabular}{|c|c|c|c|}
\hline Parameter & $\begin{array}{c}\text { COPP } \\
\text { Mean (Range) }\end{array}$ & $\begin{array}{c}\text { COP } \\
\text { Mean (Range) }\end{array}$ & $\begin{array}{c}\text { CHOP } \\
\text { Mean (Range) }\end{array}$ \\
\hline $\begin{array}{c}\text { FSH (IU/L) } \\
\text { Pre-treatment } \\
\text { Post-treatment } \\
\text { Follow-up (5 yrs.) } \\
\text { At } 20 \text { years } \\
\end{array}$ & $\begin{array}{c}5.12(2.23-5.9) \\
36.66(4.56-69.41) \\
23.81(5.4-78.12) \\
18.00(4.78-79.00) \\
\end{array}$ & $\begin{array}{c}4.98(2.56-5.6) \\
11.67(2.58-37.7) \\
3.58(2.54-6.11) \\
3.81(3.00-6.99) \\
\end{array}$ & $\begin{array}{c}8.26(4.01-22.4) \\
44.61(4.68-99.6) \\
9.99(2.5-24.89) \\
9.00(3.00-28.09)\end{array}$ \\
\hline $\begin{array}{c}\text { LH (IU/L) } \\
\text { Pre-treatment } \\
\text { Post-treatment } \\
\text { Follow-up (5 yrs.) } \\
20 \text { years } \\
\end{array}$ & $\begin{array}{c}6.30(3.12-11.0) \\
8.86(3.61-10.0) \\
12.88(3.52-23.65) \\
11.90(3.22-21.76) \\
\end{array}$ & $\begin{array}{c}7.00(3.72-10.62) \\
7.07(3.62-17.0) \\
5.53(3.62-14.02) \\
4.99(2.00-8.99)\end{array}$ & $\begin{array}{l}10.10(1.82-12.14) \\
10.44(1 / 24-11.0) \\
7.66(1.21-25.68) \\
6.84(2.09-19.78)\end{array}$ \\
\hline $\begin{array}{l}\text { Sperm count x } 10 / \mathrm{mL} \\
\text { Pre-treatment } \\
\text { Post-treatment } \\
\text { Follow-up ( } 5 \text { yrs.) } \\
\text { At } 20 \text { years }\end{array}$ & $\begin{array}{c}58.19(18.90-78.90) \\
12.00(0-67.00) \\
22.10(0-24.90) \\
24.31(0-31.00)\end{array}$ & $\begin{array}{c}79.10(23.89-156.09) \\
20.24(0-86.99) \\
30.80(23.00-65.90) \\
34.00(24.90-66.89)\end{array}$ & $\begin{array}{c}40.40(00-97.00) \\
6.40(0-28.00) \\
11.33(0-75) \\
13.99(0-67.89)\end{array}$ \\
\hline
\end{tabular}

COPP Cyclophosphamide $650 \mathrm{mg} / \mathrm{m} 2 \mathrm{~d} 1$-d8 (total $7.8 \mathrm{gm} / \mathrm{m} 2$ ), vincristine $1.4 \mathrm{mg} / \mathrm{m} 2 \mathrm{~d} 1$, d8, procarbazine $100 \mathrm{mg} / \mathrm{m} 2 / \mathrm{d}$ d1-d14, prednisolone $60 \mathrm{mg} / \mathrm{m} 2 / \mathrm{d}$ (d1-d14) [Total 6 cycles].

COPP Cyclophosphamide $750 \mathrm{mg} / \mathrm{m} 2$ (total $4.5 \mathrm{gm} / \mathrm{m} 2$ ), Vincristine $1.4 \mathrm{mg} / \mathrm{m} 2$ (total $8.4 \mathrm{mg} / \mathrm{m} 2$ ), Prednisolone $60 \mathrm{mg} / \mathrm{m} 2 / \mathrm{d}$ d1-d5 [Total 6 cycles].

CHOP Cyclophosphamide $750 \mathrm{mg} / \mathrm{m} 2$ (total $4.5 \mathrm{gm} / \mathrm{m} 2$ ), Adriamycin $50 \mathrm{mg} / \mathrm{m} 2$ (total $300 \mathrm{mg} / \mathrm{m} 2$ ), Vincristine $1.4 \mathrm{mg} / \mathrm{m} 2$, Prednisolone $100 \mathrm{mg} / \mathrm{m} 2 \times 5$ days (Total $3 \mathrm{gms}$ ). 


\begin{tabular}{|c|c|c|c|c|c|c|c|}
\hline $\begin{array}{l}\text { Values } \\
\text { (Mean) }\end{array}$ & $\begin{array}{c}\text { Pre- } \\
\text { Treatment }\end{array}$ & $\begin{array}{c}\text { At Completion } \\
\text { of Treatment }\end{array}$ & P Value & $\begin{array}{c}\text { At } \\
\text { Follow-up of } \\
60 \text { Months } \\
\end{array}$ & P Value & $\begin{array}{c}\text { At Follow-up } \\
\text { of } 20 \text { Years }\end{array}$ & P Value \\
\hline Age $<30$ & $(\mathrm{~N}=13)$ & $(\mathrm{N}=12)$ & $\begin{array}{l}\text { Pre-Treat vs } \\
\text { completion of } \\
\text { treatment }\end{array}$ & $(\mathrm{N}=10)$ & $\begin{array}{c}\text { Completion } \\
\text { versus } \\
60 \text { months }\end{array}$ & $(\mathrm{N}=9)$ & $\begin{array}{c}5 \text { years } \\
\text { versus } \\
20 \text { years }\end{array}$ \\
\hline $\mathrm{FSH}$ & 5.00 & 26.15 & $<0.05$ & 8.98 & $<0.05$ & 10.00 & $\mathrm{P}=\mathrm{ns}$ \\
\hline LH & 7.12 & 8.00 & $\mathrm{P}=\mathrm{ns}$ & 8.80 & $\mathrm{P}=\mathrm{ns}$ & 7.90 & $\mathrm{P}=\mathrm{ns}$ \\
\hline $\begin{array}{c}\text { Sperm } \\
\text { Count }\end{array}$ & 60.23 & 14.98 & $<0.05$ & 29.88 & $<0.05$ & 32.88 & $\mathrm{P}=\mathrm{ns}$ \\
\hline $\begin{array}{c}\text { Age }>30 \\
\text { years }\end{array}$ & $(\mathrm{N}=17)$ & $(\mathrm{N}=15)$ & & $(\mathrm{N}=11)$ & & $(\mathrm{N}=9)$ & \\
\hline FSH & 7.24 & 35.81 & $<0.05$ & 15.94 & $<0.05$ & 10.54 & $\mathrm{P}=\mathrm{ns}$ \\
\hline $\mathrm{LH}$ & 8.48 & 9.58 & $\mathrm{P}=\mathrm{ns}$ & 8.58 & $\mathrm{P}=\mathrm{ns}$ & 7.92 & $\mathrm{P}=\mathrm{ns}$ \\
\hline $\begin{array}{c}\text { Sperm } \\
\text { Count }\end{array}$ & 58.23 & 11.78 & $<0.05$ & 12.94 & $<0.05$ & 15.32 & $\mathrm{P}=\mathrm{ns}$ \\
\hline$P$ value & $\mathrm{P}=\mathrm{NS}$ & $\mathrm{P}=\mathrm{NS}$ & & $\mathrm{P}<0.05^{*}$ & & $\mathrm{P}=\mathrm{NS}$ & \\
\hline
\end{tabular}

\section{DISCUSSION}

Hodgkin's and non-Hodgkin's lymphoma are important malignancies for studying the gonadal toxicity of chemotherapy and radiotherapy, because it commonly affects the persons of reproductive age groups and is potentially curable in the majority of the patients. ${ }^{5}$ Pretreatment infertility is a significant problem in males having Hodgkin's lymphoma, about 20 to $30 \%$ of patients have either azoospermia or oligospermia, yet a large number of patients with Hodgkin's lymphoma have normal spermatogenesis ${ }^{6}$ with $24.5 \%$ having total sperm count of $<40 \times 10^{6}$ /ejaculate.

There is decrease in semen quality in patients with stage III and IV Hodgkin's lymphoma. ${ }^{6}$ In our study $13.20 \%$ patients had azoospermia at presentation, four times more as compared to normal population. The mean FSH and LH also showed significant variation from that of normal population comparable to other studies. Whitehead et al found sperm count of $<20 \times 10^{6} / \mathrm{mL}$ in $20 \%$ of lymphoma patients. ${ }^{7}$ Cigessky noticed decreased sperm count in $40 \%$ of men with Hodgkin's lymphoma. ${ }^{8}$ Comparatively low incidence of azoospermia in our study may be related to younger age (19 to 44 years) and majority of the patients had early stage disease (Stage I and II). The pathogenesis of pretreatment infertility is unclear and complex, perhaps because of involvement of both pituitary and gonads. ${ }^{8}$

Ageing has been associated with hormonal changes leading to decreased spermatogenesis. In our study, major difference in FSH levels of two groups was found at follow-up being significant in favour of age $<30$ years. Sperm counts recovered to normal in $59.61 \%$ of patients of $<30$ years age and in $18.69 \%$ of $>30$ years of age $(p<0.05)$.

Difference in histology between Hodgkin's and nonHodgkin's lymphoma did not reveal any significant variation in testicular activity before or after treatment. On comparing mean FSH, LH and sperm counts in two groups, the difference was insignificant. The percentage of patients who achieved normospermia at follow-up did not vary significantly.

As per the drug regimens used, COPP has been documented to be most gonadotoxic. Procarbazine containing regimes result in prolonged azoospermia in the vast majority of patients. 2,5,9,10 But much lesser degrees of long-term gonadal toxicity are apparent with the newer forms of chemotherapy.111,5 In our study, patients who received COPP had $100 \%$ normospermia before treatment.

Following treatment more than $91 \%$ continued to have azoospermia at a follow-up of five years, which is similar to other studies 9,12 (Table 3). The effect of cyclophosphamide and procarbazine combination on sperm count and hormone levels (FSH) was significant. The overall recovery rate in our study was $25 \%$ at follow-up of 5 years. FSH levels showed a significant decline as compared to the levels at the completion of treatment $(p<0.05)$. No further improvement was demonstrated at follow-up of 20 years, FSH levels had a gradual decline, but continued to remain four-fold higher than normal. COP was the safest regimen used. FSH had a two-fold rise, but returned to normal at follow-up with sperm count showing a significant increase.

Roeser et al has demonstrated azoospermia in 30\% patients at a follow-up of 34 months. ${ }^{13}$ Cyclophosphamide in a dose of 4 to $7 \mathrm{gm} / \mathrm{m}^{2}$ produced azoospermia in all men, but recovery occurred in $100 \%$ after a follow-up of 31 months. ${ }^{14}$ Lopez et al in their study showed cumulative cyclophosphamide dose and basal Follicle Stimulating Hormone (FSH) levels were identified as independent factors associated with azoospermia or severe oligo-azoospermia. 15 Pryzant et al demonstrated 100\% azoospermia following chemotherapy with CHOP combination, $66.6 \%$ of whom showed recovery to normal counts at a follow-up of 7 years. ${ }^{16}$

Sherins et al postulated that recovery of spermatogenesis even after extensive chemotherapy is possible, more likely to occur after more than 2 years of followup. ${ }^{17}$ Patients having the largest reductions in their sperm concentration after treatment required the longest recovery period for spermatogenesis. This is evident from a study conducted by Bahadur et al in patients with lymphoma and leukaemia over a 26-year period. ${ }^{4}$ Chapman et al found that recovery in spermatogenesis was unlikely after five years. ${ }^{18}$

In our study also, difference in mean FSH levels in patients at 1 year or $>5$ year follow-up was significant; recovery of normal sperm count at 5-year follow-up compared patients having $<1$ year follow-up $(\mathrm{p}<0.01)$. The mean pretreatment FSH was $6.12 \mathrm{IU} / \mathrm{L}$, which after completion had a five-fold rise and then declined to $12.46 \mathrm{IU} / \mathrm{L}$ at 5-year followup associated with a similar variation in sperm count as depicted in Table 1. FSH levels and sperm count did not 
demonstrate any significant change at 20 years follow-up with FSH remaining still high at $10.27 \mathrm{IU} / \mathrm{L}$ and sperm count low at $24 \times 10^{6} \mathrm{IU} / \mathrm{L}$ (Table 1). The severity of the reduction in sperm concentration following treatment is unpredictable; likely to be more severe in patients treated with radiotherapy and alkylating agents. 19

\section{CONCLUSION}

To conclude the effect of cyclophosphamide and procarbazine containing chemotherapy is significant compared to the patients who received combinations without procarbazine. Initial recovery of testicular functions achieved at 5 years was less likely to improve significantly even after a prolonged follow-up period of 20 years.

\section{REFERENCES}

1. Meistrich ML. Critical components of testicular function and sensitivity to disruption. Biol Reprod 1986;34(1):17-28.

2. Howell SJ, Shalet SM. Testicular functions following chemotherapy. Hum Reprod Update 2001;7(4):363-369.

3. Fegan JE, Larry I, Lipshultz MD. Abnormalities of the testes leading to male infertility: evaluation and diagnosis. Hospimedica 1988;6(1):33-40.

4. Relander T, Cavallin-Ståhl E, Garwikz S, et al. Gonadal and sexual function in men treated for childhood cancer. Med Paediatr Oncol 2000;35(1):52-63.

5. Dubey P, Wilson G, Mathur KK, et al. Recovery of sperm production following radiation therapy after induction chemotherapy with mitoxantrone, vincristine, vinblastine and prednisone (NOVP). Int J Radiation Oncology Bio Phys 2000;46(3):609-617.

6. Gaudini L, Lambardo F, Salacone P, et al. Testicular cancer and hodgkin's disease: evaluation of semen quality. Hum Reprod Update 2003;18(4):796-801.

7. Whitehead E, Shalet SM, Blackledge G, et al. The effects of hodgkin's disease and combination chemotherapy on gonadal function in adult male. Cancer 1982;49(3):418422.

8. Vigersky RA, Chapman RM, Berenberg J, et al. Testicular dysfunction in untreated hodgkin's disease. Am J Med 1982;73(4):482-486.
9. Kreuser ED, Xiros N, Hetzel WD, et al. Reproductive and endocrine gonadal capacity in patients treated with COPP chemotherapy for hodgkin's disease. J Cancer Res Clin Oncol 1987;113(3):260-266.

10. Navsmith TE, Blake DA, Harvey VJ, et al. Do men undergoing sterilizing cancer treatments have a fertile future? Hum Reprod 1998;13(11):3230-3235.

11. Bahadur G, Oturk O, Muneer A, et al. Semen quality before and after gonadotoxic treatment. Hum Reprod 2005;20(3):774-781.

12. Charak BS, Rahul G, Pranto $M$, et al. Testicular dysfunction after cyclophosphamide, vincristine, procarbazine, prednisolone chemotherapy for advanced hodgkin's disease. A long-term follow-up study. Cancer 1990;65(9):1903- 1906.

13. Da Cunha MF, Meistrich ML, Fuller LM, et al. Recovery of spermatogenesis after treatment for hodgkin's disease: limiting dose of MOPP chemotherapy. J Clin Oncol 1984;2(6):571-577.

14. Chapman RM. Gonadal effects of chemotherapy in men and boys. In: Perry MC, ed. Chemotherapy source book Pub: William's \& Wilkins USA, 1992;1st edn:730-752.

15. Lopez Andreu JA, Pernandez PJ, Ferrisi Torlajada J, et al. Persistent altered spermatogenesis in long term childhood cancer survivors. Paediatr Haematol Oncol 2000;17(1):21-30.

16. Pryzant RM, Meistrich ML, Wilson G, et al. Long term reduction in sperm count after chemotherapy with and without radiation therapy for non-hodgkin's lymphomas. J Clin Oncol 1993;11(2):239-247.

17. Sherins RJ, Devita VT. Effect of drug treatment for lymphoma on male reproductive capacity: studies of men in remission after therapy. Ann Int Med 1973;79(2):216-220.

18. Chapman RA, Sutcliffe SB. Rees LH, et al. Cyclical combination chemotherapy and gonadal function. Retrospective study in males. Lancet 1979;1(8111):285289.

19. Chapman RM, Sutcliffe SB, Malpas JS. Male gonadal dysfunction in hodgkin's disease. A prospective study. JAMA 1981;245(13):1323-1328. 